УДК 338.24:37.014.54 (477):378.112

\title{
FEATURES OF THE INNOVATIVE FORMS OF INTEGRATION FOR THE ENTREPRENEURIAL UNIVERSITIES
}

\section{ОСОБЛИВОСТІ \\ ІННОВАЦІЙНИХ ПІДПРИЕМНИЦЬКИХ УНІВЕРСИТЕТІВ}

\section{ОСОБЕННОСТИ ИННОВАЦИОННЫХ ФОРМ ПРЕДПРИНИМАТЕЛЬСКИХ УНИВЕРСИТЕТОВ}

ФOPM
ІНТЕГРАЦІї

ИНТЕГРАЦИИ

\author{
Mytsiuk S.
}

Ph.D. (economics), Senior Researcher of Taras Shevchenko National University of Kyiv. E-mail: marimax@bigmir.net

\section{Мицюк С. В.}

Кандидат економічних наук, старший науковий співробітник Київського національного університету імені Тараса Шевченка. E-mail: marimax@ bigmir.net

\section{Мицюк С. В.}

Кандидат экономических наук, старший научный сотрудник Киевского национального университета имени Тараса Шевченко E-mail: marimax@bigmir.net

Abstract. The article substantiates the necessity and determination of the prospects for the innovative development of intellectual resources in the conditions of the formation of entrepreneurial-type universities in Ukraine. The process of transformation of the role of intellectual capital in the modern economy is analyzed, the evolution of approaches to the development of universities is studied, the specifics of the formation of entrepreneurial-type universities are defined, and intellectual resources are designated as a factor in the development of modern universities. The possibility of creating a fundamentally integrated integrated structure of a priority technological platform, including a HEI, research institutions and enterprises, an innovative integrated structure, has been determined. Also considered are important innovative forms of integration of science, business and education - clusters and public-private partnerships. The role of the state in supporting the development of interaction between enterprises and scientific and educational organizations has been determined. The article examines the global trends in the development of universities: general patterns and national characteristics, analyzes patterns and prerequisites for the formation of entrepreneurial-type universities in Ukraine, and defines the values of intellectual resources in the formation of entrepreneurial-type universities. The article considers the innovative development of intellectual resources in the context of the formation of entrepreneurial-type universities, identifies promising areas for enhancing the innovative development of intellectual resources. The algorithm for introducing the competence approach to the process of innovative development of intellectual resources for the formation and development of business-type universities in Ukraine is analyzed.

Keywords: entrepreneurial university, innovation, intellectual capital, knowledge transfer, clusters.

Анотація. В статті обтрунтовано необхідність та визначення перспектив інноваційного розвитку інтелектуальних ресурсів в умовах формування університетів підприсмницького типу в Україні. Проаналізовано процес трансформаціі ролі інтелектуального капіталу в умовах сучасної економіки, досліджено еволюцію підходів до розвитку університетів, визначено специфіку формування університетів підприємницького типу, інтелектуальні ресурси позначені як фактор розвитку сучасних університетів. 
Визначено можливість створення принципово нової інтегрованої структури пріоритетної технологічної платформи, щзо включає 3ВО, науково-дослідні установи і підприємства інновачійна інтегрована структура. Розглянуто також важливі інноваційні форми інтеграчії науки, бізнесу $і$ освіти - кластери та державно-приватні партнерства. Визначено роль держави в підтримизі розвитку взаємодії підприємств $і$ науково-освітніх організацій. В статті досліджені глобальні тенденції розвитку університетів: загальні закономірності і національні особливості, проаналізовано закономірності та передумови формування університетів підприємницького типу в Україні, визначено значення інтелектуальних ресурсів у формуванні університетів підприємницького типу. В статті розглянуто інноваційний розвиток інтелектуальних ресурсів в умовах формування університетів підприємницького типу, визначені перспективні напрями активізації інноваційного розвитку інтелектуальних ресурсів. Проаналізовано алгоритм впровадження компетентнісного підходу в процес інноваційного розвитку інтелектуальних ресурсів для формування і розвитку університетів підприємницького типу в Україні.

Ключові слова: підприємницькій університет, інновації, інтелектуальний капітал, трансфер знань, кластери.

Аннотация. В статье обоснована необходимость и определение перспектив инновачионного развития интеллектуальных ресурсов в условиях формирования университетов предпринимательского типа в Украине. Проанализирован прочесс трансформации роли интеллектуального капитала в условиях современной экономики, исследована эволючия подходов $к$ развитию университетов, определена специфика формирования университетов предпринимательского типа, а интеллектуальные ресурсы обозначены как фактор развития современных университетов. Определена возможность создания принципиально новой интегрированной структуры приоритетной технологической платформы, включающей ВУЗы, научно-исследовательские учреждения $и$ предприятия - инноваџионная интегрированная структура. Рассмотрены также важные инновачионные формы интеграции науки, бизнеса и образования - кластеры $и$ государственно-частные партнерства. Определена роль государства в поддержке развития взаимодействия предприятий и научно-образовательных организаций. $B$ статье исследовань глобальные тенденции развития университетов: общие закономерности $u$ начиональные особенности, проанализированы закономерности и предпосылки формирования университетов предпринимательского типа в Украине, определень значения интеллектуальных ресурсов в формировании университетов предпринимательского типа. $B$ статье рассмотрено инновачионное развитие интеллектуальных ресурсов в условиях формирования университетов предпринимательского типа, определены перспективные направления активизации инновачуионного развития интеллектуальных ресурсов. Проанализирован алгоритм внедрения компетентностного подхода в прочесс инновачионного развития интеллектуальных ресурсов для формирования и развития университетов предпринимательского типа в Украине.

Ключевые слова: предпринимательский университет, инновации, интеллектуальный капитал, трансфер знаний, кластеры.

Formulation of the problem. Under the influence of market and globalization processes in the modern Ukrainian economy there is a transformation of the higher education sphere, which is connected to the growing competition of universities, the increasing of their independence and rigid consumer demands. In this regard, the urgency of the formation of business-type universities adapted to the new economic conditions is increasing.

The purpose of the article. The purpose of this study is to substantiate the need and identify the prospects for innovative development of intellectual resources in the conditions of the formation of business-type universities in Ukraine. 
Analysis of recent research and publications. Problems of development of higher education institutions (HEI), patterns and tendencies of their modern progress, innovative forms of integration of business universities are investigated by domestic and foreign scientists, in particular: I. Artyomov, B. Clark, H. Etzkowitz, M. Zgurovsky, T. Koroleva, V. Lugovoi, T. Mirzodaeva, O. Romanovsky, V. Smolanka and others.

Outline of the main research material. Current trends in the global economic space reveal a shift of the vector of its development in the direction of innovation. A new type of economy is emerging, that is, an economy where the latest knowledge is the defining resource. And the need to reproduce the latest knowledge in the context of institutional gaps between the development of innovations and their commercialization provokes the creation of innovative structures for the organization of innovative activities, namely the organizational mechanism for multilateral interaction between subjects of the real sector of economy, scientific and educational organizations and public administration, which is implemented different innovative concepts of «universitiesenterprises» and «state-universities» and entrepreneurial structures of innovation type, both nationally and internationally.

For example, J. Ropke examines entrepreneurial universities three-way, defining this concept, first, as a higher education institution that performs entrepreneurial functions; secondly, it finds expression in the entrepreneurial activity of university staff and students; third, it means the development of cooperation between higher education institutions and the external environment (in particular the business sector) [Röpke, 2000].

A fundamentally new integrated structure could be a prioritized technology platform, including HEIs, research institutions and enterprises - an innovative integrated structure. Such a structure is defined as «a set of business entities connected to each other by a network system of financial and economic relations aimed aimed to improve the efficiency of participants' innovation activities through optimization of resources» [Харин, 2012]. The role of the state is to support the development of interaction between enterprises and scientific and educational organizations, by creating conditions for expanding the practice of involving higher education institutions in the activities carried out by organizations of the real sector of economy in the field of research, research and development, and technological works, as well as to develop the potential of higher education institutions as research (design, engineering) organizations. The mechanism of integrational interaction is the creation of a research center, which will be the intermediary structure between the patent and the publication. Improving the effectiveness of innovation can also be about creating technology platforms. It is an amalgamation of science, business and education in areas that are of national interest not only in Ukraine but also in other countries. The technology platform, as an innovative integrated structure, is of particular interest in such areas as: information and space technologies, energy, transport, lasers, biotechnology, pharmacy and fine chemistry.

Another innovative form of integration of science, business and education - the form of clusters, which can be divided into: educational and mixed («scientific-educational» and «industrial-educational») should also be noted. Here, the cluster acts as an integration mechanism that ensures the intensive development and social partnership of the organizations that form it. Like all integrated cluster structures, clusters are created to increase the resource base and facilitate access to new technologies, to increase external and internal consumer markets, to integrate the research base and to ensure openness to the use of scientific knowledge. Depending on the shape of the cluster, the core of the cluster may be organizations and enterprises that produce end products or educational institutions [Смоланка, 2015].

Educational clusters involve collaboration between other educational institutions. The nucleus of such a cluster is the university. Collaboration within the educational cluster involves the research activities of the subjects of the educational system both vertically and horizontally. Advantages of cluster creation are exchange of technologies, knowledge, skills development among labor resources, advantages of agglomeration and social infrastructure [Корольова, 2009].

The form of integration of education, the state and business as a public-private partnership should also be mentioned. Public-private partnership is characterized as a union of the state and the 
HEI to create a favorable investment climate in order to generate demand for innovation. Such an association involves the construction of a risk-based management mechanism whereby research and development is carried out on the basis of the intellectual capital of the HEI, the investment capital of the state and state property. This requires the active use of public procurement and public procurement tools as a tool for providing state support. In Europe, for example, some forms of integration are the result of state reforms, while others are emerging in order to concentrate research capacity to function effectively in a highly competitive global market and compete with commercial corporations funded by large corporations [Романовський, 2012].

Through the reproduction of intellectual property and labor resources, the potential of intellectual capital of an innovative integrated structure (organizations, enterprises and the state) is increased. In the structure of intellectual capital, researchers distinguish the static part - many objects of intellectual property, production, providing technology, and the dynamic part in the form of specialists, ensuring its development. The potentials of the static and dynamic parts are formed in the continuous interaction of asymmetric structures: education, science and production systems based on the principle of asymmetry. In order to carry out research-intensive research and development, it is necessary that the potential of the dynamic part of the intellectual capital of an innovative organization exceeds its static potential.

As an integrated form of organization of the system of education and business should be mentioned the concept of the triple helix of H. Etzkowitz and L. Leidesdorf «university-enterprisestate», which appeared as the intersection of two so-called double helices: «university-enterprise» and «state-universities» [Etzkowitz, 2002]. The concept is based on the transformation, displacement and expansion of priorities in the activities of the members of the association, and on the possibility of effective mutual exchanges of functions and results of activities, as well as, within the framework of the triple helix, their sustainable reproduction [Etzkowitz, $2000 \mathrm{a}$ ]. Thus, according to $\mathrm{H}$. Etzkowitz, the traditional regulatory and guiding role of the state is expanding somewhat, since, by creating funds for financing innovative business, the state fulfills the role of business [Etzkowitz, 2007]. Business structures, by providing educational services and improving curricula, perform the functions of the education system. Universities, by creating innovative companies such as business incubators, techno parks, business centers, and so on, to commercialize knowledge and increase extra-budgetary income, as well as through paid educational services (educational entrepreneur), begin to fulfill the role of business, the role of entrepreneurship. In the triple helix model, a balance of interests is achieved and cooperation is developed which develops in the most effective direction. H. Etzkowitz views the triple helix not only as a collaboration of three institutional forms, but also as an interaction of three spaces: a space of knowledge, a space of agreement and a space of innovation [Etzkowitz, 2008]. The knowledge space is an existing intellectual potential (intellectual property objects, publications, and so on) capable of generating knowledge. The space of consent implies cooperation between different institutional spheres in order to identify competitive advantages, strengths and weaknesses of the region and formulate directions for development. It can be embodied in the form of newly created firms (venture, consulting). Innovation space is the creation of a new kind of organization for the implementation of an innovative project using the resources (financial, technological, intellectual) of all institutional actors [Etzkowitz, 2005].

In these circumstances, classical universities are being transformed into entrepreneurial universities, which play a leading role in the triple helix model.

The problems of forming a business university were first considered by B. Clark in the work «Creating a business university: organizational directions of transformation». Analyzing over the past ten years the activities of the EWF Twente (Netherlands), Warwick (UK), Chalmers (Sweden), Strathclyde (Scotland), Joensuu (Finland), B. Clark has identified their transformation in the direction of active entrepreneurial activity. B. Clark defines an entrepreneurial university as a university ready to «take risks when developing new practices, the outcome of which is unclear» [Clark, 2008]. From the standpoint of the researcher, the University of Entrepreneurship has a significant difference from the classical university - it is a willingness to commercialize the 
generation and dissemination of knowledge. From the perspective of Joule Ropke, the distinctive features of an entrepreneurial university should be: the entrepreneurial behavior of the organization, the entrepreneurial behavior of teachers, students, staff, as well as the structural interaction of the entrepreneurial university and the region. This is why the University of Business should be open to organizational change and the introduction of innovative ideas.

Forming such traits requires active work on adapting employees to changes in HEI, developing entrepreneurial thinking and involving most employees in the process of generating innovative ideas and making management decisions. Entrepreneurial values should become fundamental to both the teaching staff and students involved in project implementation. According to B. Clark, HEI, marking the task of transforming into a business-type university, should carry out deliberate actions to reorganize the structure and reorient its philosophy of activity to the position of entrepreneurship [Clark, 2008]. Another way of forming an entrepreneurial university is to create the conditions that are most conducive to developing initiative for teachers and students to create innovative companies.

Their leading position is explained by the fact that universities unite in their education system all major branches of science and, therefore, have the greatest intellectual potential. Within entrepreneurial universities, teaching, research and entrepreneurship combine to generate revenue through commercialization of innovation. As teachers and students are involved in the entrepreneurial activity of the university within the framework of an innovative business structure, there is an accelerated implementation of the latest applied knowledge in the educational process. The formation of new knowledge and their capitalization ensure the accelerated development of intellectual resources and, as a consequence, innovative activity. Thus, business universities carry out not only the classical functions of HEI: educational, research, intellectual, supplementary and continuing education, cultural, economic, social, but also fundamentally new functions: knowledge transfer, generation of scientific ideas, entrepreneurship, investment.

In developed countries universities are given the key role of economic engines in the process of creating new knowledge, transferring it to the non-academic sector and commercializing it. At the same time, universities directly influence the development of an entrepreneurial society, enriching students with appropriate skills and knowledge, so knowledge transfer activities are among the key components of university development. In particular, the structure of the University of Edinburgh has a technology-transfer center, which was created in conjunction with the city hall of the city. This center includes units that deal with the transfer of research results to interested enterprises, marketing research, intellectual property issues, and an incubator of innovative companies, which carries out the final verification of research projects initiated by university professors, search for partners in the field of commercialization projects and more [North, 2008].

Knowledge transfer is designed to ensure the transfer of knowledge, including technology, experience and skills, from the university to external customers - businesses, public and government entities, leading to innovation in the economy and public sphere. It is possible provided that at the highest level the university pursues the traditional areas of activity - research and education.

Generation of scientific ideas is the most important function of an entrepreneurial university. Within the University there is an active research, educational activity, filled with creative ideas of young researchers. Obtaining grants, conducting their own research, experience, participation in conferences and seminars constitute the innovative activity of the HEI, which generates new creative ideas that require careful analysis to form a new innovative area of activity. The realization of the entrepreneurial function implies the creation within the framework of HEI, as well as separate structural units of small innovative enterprises, where in the process of work, through commercialization of ideas students with the participation of teachers and entrepreneurs could gain practical experience of real entrepreneurial activity.

The entrepreneurial university builds its activity in such main areas as: training of innovatively active specialists, production of high-tech ideas, technologies, innovations and their commercialization (capitalization of knowledge). Thus, the Entrepreneurial University carries out 
its activity not only in the direction of study, carrying out scientific researches, but also in the direction of attraction to the universities of investments from the state and business, profit from own business activity [Міроздаєва, 2012]. As a result of cooperation with other institutional forms (state and business), the university makes a significant contribution to the socio-cultural development of the region. In their studies, some scholars have found a direct relationship between the capitalization of knowledge and the internal factors of university transformation. Differences in the goals of the members of a tripartite association are overcome within the framework of an entrepreneurial university, which enables the interaction of these different value propositions. The main factor is the scientist. Researchers point out that «before considering the capitalization of knowledge, we must take into account the microstructure of the motivation, norms, potential and resources of the particular scientist involved in the production of innovation». H. Etzkowitz emphasizes the importance of human resources: «without the individual contribution of a scientist, it is impossible to develop a model» [Etzkowitz, $2000 \mathrm{~b}$ ]. Moreover, as a result of the movement of human resources within the model, as well as being an element of two or three institutional spheres (a combination of teaching and work in a company or successful entrepreneurship) forms, methods, tools of teaching activity are updated and determine a significant increase in knowledge. At the same time even at the most entrepreneurial universities only a relatively small percentage of the faculty are interested in becoming directly involved in technology transfer [Etzkowitz, 2010].

Therefore, it is quite obvious that classical universities are undergoing significant changes and are gradually being transformed into entrepreneurial (innovative, research), which determines the formation of new structures of organization of innovative activity. This, for example, an innovative integrated structure (technology platforms) includes: HEIs, research institutions and enterprises; the triple helix model includes: university, enterprise, state. Universities play a major role here [Луговий, 2012].

Within the framework of entrepreneurial universities, competitive scientific groups are formed, which, through modern innovative structures of the entrepreneurial type (centers, laboratories, departments), carry out patent-licensing activity, commercialization of research and development, knowledge transfer. Taking into account scientific and applied research of domestic and foreign scientists, we can distinguish the following principles of activity of business universities: entrepreneurial thinking of teachers, students, staff, their ability to adapt and change; entrepreneurial activity, openness to organizational change and implementation of innovative ideas; high level of scientific research; systematic organizational and economic relations of all members of the association; developing their potential through knowledge gains; integration of different styles and value systems; maintaining a balance of interests.

Entrepreneurial universities do not only carry out the classical functions of HEI: educational, research, intellectual, supplementary and continuing education, cultural, economic, social. In the activity of business universities, fundamentally new functions are added: training of innovatively active specialists, transfer of knowledge, generation of scientific ideas, production of high-tech ideas, technologies, innovations, commercialization (capitalization of knowledge) of development, attraction of investments. The university is a place where thousands and tens of thousands of students come up with new ideas, and these ideas can be successfully commercialized and marketed under favorable conditions [Згуровський, 2011].

It should be noted that in Ukraine there has been a process of changing the classical paradigm of education. There is a need for gradual formation and implementation of the higher education model, which is based on the integration of educational institutions into large educational and scientific-industrial clusters, as a result of which HEIs will gradually begin to acquire entrepreneurial specificity of activity. The higher education institution's innovation system is an organizational and managerial mechanism for developing and implementing innovations to enhance its competitiveness.

After all, foreign and domestic experience shows that solving the problem of building a modern competitive economy and knowledge society requires optimal use of the latest models of innovation processes, an important component of which are research innovation universities [20]. 
Conclusions. Thus, the modern innovation space is characterized by a variety of forms and structures that unite such institutions of economy as: the state, education, business, science. It is necessary to distinguish such organizational forms and associations of subjects of innovative activity as: technological platforms, clusters, educational clusters, public-private partnership, «knowledge triangle», «triple spiral». The reasons for such integration are the transformation, displacement and expansion of the priorities of functioning of the subjects of innovative activity. The purpose of such an association is to increase the efficiency of innovation activities of its participants and the country as a whole. The main role in all integration structures belongs to the university, as a leading link in the system of generation and commercialization of new knowledge. Universities, by creating innovative companies, such as business incubators, techno parks, business centers, and so on, with the aim of commercializing knowledge and increasing extra-budgetary revenues, as well as providing paid educational services, are beginning to fulfill the role of business, the role of entrepreneurship and are transformed into business universities. This ensures the fulfillment by them of the real tasks of state or entrepreneurial structures, the participation of students and teachers in scientific research funded not only by business, but also by the state [Грищенко, 2015].

The transformation of universities into entrepreneurial ones is due to the availability of the necessary components: the innovation policy of the HEI; entrepreneurial transformations that can occur only under the direct influence of innovative relations in the staff of the educational institution; formed corporate entrepreneurial culture. The nature of these relationships can either contribute to or counteract the implementation of entrepreneurial ideas in the HEI [Романовський, 2015].

\section{References}

1. Clark B. R. (2008). Creating Entrepreneurial Universities: Organizational Pathways of Transformation. Iau Press. Issues In Higher Education. Wagon Lane, Bingley BD16 1WA. UK: Emerald Group Publishing Limited. Howard House, 164 p.

2. Etzkowitz H. (2002). Incubation of incubators: innovation as a triple helix of universityindustry - government networks. Science and Public Policy, 29(2): 115-128.

3. Etzkowitz H., Chunyan Zhou (2007). Regional Innovation Initiator: The Entrepreneurial University in Various Triple Helix Models. The paper for Triple Helix VI conference, Singspore, May 16-18.

4. Etzkowizt H., Goktepe-Hulten D. (2010). Maybe they can? University technology transfer offices as regional growth engines. Int. J. Technology Transfer and Commercialisation, 9(1/2): $166-181$.

5. Etzkowitz H., Klofsten M. (2005). The Innovating Region: Towards a Theory of Knowledge Based Regional Development. Research Management, 35(3): 243-255.

6. Etzkowitz H., Loe L. (2000). The Dynamics of Innovation: From National System and «Mode 2» to a Triple Helix of University-Industry-Government Relations. Research Policy, 29: $109-123$.

7. Etzkowitz H., Webster A., Gebhardt C., Terra B.R.C. (2000). The future of the university and the university of the future: evoluation of ivory tower to entrepreneurial paradigm. Research Policy, 29: 313-330.

8. Etzkowitz H. (2008). The Triple Helix: University-IndustryGovernment Innovation In Action. London: Routledge, 2008. 177 p.

9. North $K$. The anatomy of European knowledge regions: a comparative analysis. Forth world conference on intellectual capital for communities. Paris, May 2008. $<$ http//www.web.worldbank.org>

10. Röpke J. The Entrepreneurial University, Innovation, academic knowledge creation and regional development in a globalized economy. Working Paper Department of Economics, 
5.1.2000.p. 3 .<http://etc.online.unimarburg.de/LinkedDocuments/mafex_rj_entreuni.pdf >.

11. Грищенко I.M. (2015). Теоретико-методологічне обгрунтування ефективних фінансово-економічних моделей розвитку вищої иколи [Theoretical and methodological substantiation of effective financial and economic models of higher education development]. Монографія (рукопис); за заг. ред. чл.-кор. НАПН України, д-ра екон. наук., проф. I. М. Грищенка. К., 2015. 236 с.

12. Згуровський М. 3. (2011) Дослідницькі університети як центри інноваційного розвитку країни [Research universities as centers of innovative development of the country]. Дзеркало тижня. 22-28 січня 2011 р. № 2. С. 1-13.

13. Корольова Т. С. (2009) Складові інноваційної системи вищих навчальних закладів [Тhе Components of the innovational system of higher education institutions] Культура народів Причорномор'я. Секція: Економіка. Сімферополь: Міжуніверситетський центр «Крим», 2009. № 171. С. 42-45.

14. Луговий В.І. (2012) Економічно-організачійні засади освіти в Україні та світі: порівняльний аналіз [Economic and organizational principles of education in Ukraine and the world: a comparative analysis]. Педагогіка і психологія. 2012, № 1. С. 64-70.

15. Мірзодаєва Т. В., Романовський О. О. (2012) Концептуальні підходи до формування міждержавних інноваційно-освітніх мереж підприємницького типу [Conceptual approaches to the formation of interstate business-type innovation-educational networks]. Міжнародний науковий вісник. Ужгород: Зак ДУ. 2012. Вип.5(24). С. 328.

16. Романовський О.О. (2012) Феномен підприємництва в університетах світу: монографія [The phenomenon of entrepreneurship in universities in the world: a monograph]. Вінниця: Нова Книга. 2012. 504 с.

17. Романовський О. О. Розвиток академічного підприємництва і підприємницьких вищих навчальних закладів в умовах глобалізації [Development of academic entrepreneurship and entrepreneurial higher education institutions in the context of globalization]. <http://www.economy.nayka.com.ua/pdf/11_2015/16.pdf>

18. Смоланка B. I., Артьомов I. B. Інноваційна діяльність університетів України: аналітичний огляд: передмова [Innovation activity of Ukrainian universities: analytical review: preface]. Інформаційний бюлетень наукового проекту «Інноваційний університет інструмент інтеграції в європейський освітній і науковий простір». Ужгород. 2015. Випуск 1, <https://www.uzhnu.edu.ua/uk/infocentre/get/9718>

19. Харин А. А. (2012) Методология формирования инновачионных интегрированных структур образования, науки и бизнеса: диссертация на соискание степени доктора экономических наук: по спеичальности 08.00.05 [Methodology of formation of innovative integrated structures of education, science and business: the dissertation for the degree of Doctor of Economic Sciences: in the specialty 08.00.05]. ГОУВПО «Государственный университет управления». М., 2012. 304 с.

20. Інновачійні дослідницькі університети як чинник модернізащії освітньо-наукової сфери та розбудови суспільства знань. Аналітична записка [Innovative research universities as a factor in modernizing the educational and scientific sphere and building a knowledge society], http://www.niss.gov.ua/articles/1427/. 